NBER WORKING PAPER SERIES

\title{
CENTRALIZATION, FISCAL FEDERALISM AND PRIVATE SCHOOL ATTENDANCE
}

Thomas J. Nechyba

Working Paper 8355

http://www.nber.org/papers/w8355

\author{
NATIONAL BUREAU OF ECONOMIC RESEARCH \\ 1050 Massachusetts Avenue \\ Cambridge, MA 02138 \\ July 2001
}

Support from the National Science Foundation (SBR-9809269, SBR-9905706) is gratefully acknowledged. The paper has benefitted from discussions at the 1999 American Economic Association Meetings, the 2000 NSF/NBER Decentralization Conference, and seminar presentations at the University of Colorado-Boulder, the University of Michigan-Ann Arbor, Northwestern University, New York University, the University of Pennsylvania, Stanford and Tulane. It owes particular debt to detailed early comments from Richard Romano as well as the comments of anonymous referees. All remaining errors are, of course, mine. The views expressed herein are those of the author and not necessarily those of the National Bureau of Economic Research.

(C) 2001 by Thomas J. Nechyba. All rights reserved. Short sections of text, not to exceed two paragraphs, may be quoted without explicit permission provided that full credit, including (C) notice, is given to the source. 
Centralization, Fiscal Federalism and Private School Attendance

Thomas J. Nechyba

NBER Working Paper No. 8355

July 2001

JEL No. H7, I2

\begin{abstract}
This paper uses a computational general equilibrium model to analyze the impact of public school finance regimes on rates of private school attendance. It is shown that, when viewed in such a general equilibrium context, state intervention in locally financed systems can have somewhat unexpected and counterintuitive effects on the level of private school attendance. In particular, the common perception that centralization of public school finance will necessarily lead to greater private school attendance is no longer correct when general equilibrium forces are taken into account - even when that centralization involves an extreme equalization of the kind observed in California. Furthermore, if centralization occurs through less dramatic means that allow for some remaining discretion on the part of local districts, declines in private school attendance become much more unambiguous and pronounced. These results then weaken the speculation that low exit rates to private schools in centralizing states imply that general public school quality does not drop as a result of such centralization.
\end{abstract}

Thomas J. Nechyba

Department of Economics

Duke University

Durham, NC 27708

and NBER

nechyba@econ.duke.edu 


\section{Introduction}

Primary and secondary public education in the US is subject to two important forces that have previously been dubbed "voice" and "exit" (Hirschman(1970)). A vast majority of parents send their children to public schools and "voice" their preferences through the political process, their choice of school districts and their involvement in local schools. A small but sizeable minority (12.8\%), on the other hand, "exit" the public system and choose private schools for their children. My aim in this paper is to address the extent to which public school financing institutions may impact the decision of parents to choose the second of these options in light of the general equilibrium forces inherent in any district based public school system. These general equilibrium forces are shown to be not only theoretically interesting but also potentially large in magnitude, and they suggest that conventional wisdom regarding the theoretical impact of public school finance centralization on private school attendance rates may need modification.

\subsection{The "Direct" Effect of Centralization on Private School Attendance}

To clarify issues, suppose that the choice a state faces is between (1) pure local funding of public schools (determined through local voting on property tax rates) under which large differences in spending levels may emerge across school districts, and (2) pure state funding (determined through state-wide voting on income tax rates) under which all public schools receive the same funding per pupil. Conventional wisdom on the impact of such state versus local public school financing institutions on private school attendance is then straightforward and closely related to Oates' Decentralization Theorem (Oates (1972)). Local provision of public goods and services, under this view, allows differing households to self select (Tiebout (1956)) 
into jurisdictions whose tax/public goods packages match most closely to household preferences. Since state financing would equalize spending in all districts at levels somewhere between the high and low levels of spending observed under local financing ${ }^{2}$, individual households that value education are thus less able to use Tiebout sorting to achieve their preferred spending levels under state financing and thus have a greater incentive to exit the public system. Therefore, the prediction arising from this conventional wisdom is that state financing will lead to an increase in the share of households choosing private schools for their children even if public schools themselves utilize resources no less efficiently under centralization (as is often hypothesized in the literature). The fact that private school attendance has not increased significantly as a result of centralization in some of the most studied cases (such as California) has therefore been suggested to imply that parents view state run (equalized) public schools similarly in quality to locally run schools. After all, they clearly are not responding in large numbers by "exiting" the centralized public system but rather continue to exercise their "voice" within the public system. ${ }^{3}$

Even the logic of the Decentralization Theorem, however, gives rise to a much more ambiguous prediction once we take into account that private school attendance occurs as much in poor districts as it does in wealthy ones. If equalization lowers public school quality in wealthy areas (thus causing an increase in private school attendance), it presumably also raises quality in poor areas (thus causing a decrease in private school attendance there). The net effect on state-

\footnotetext{
${ }^{2}$ Sonstelie and Silva (1995) demonstrate that the skewedness of the state income distribution will generally cause state spending levels to lie below the mean of local spending levels.

${ }^{3}$ In their recent comprehensive analysis of the evidence on California, for instance, Sonstelie, Brunner and Ardon conclude that "although California parents had ample reason to be discouraged about their public schools, their discouragement was not great enough to cause a significant exodus to the private sector."
} 
wide private school attendance is therefore not at all clear even when we simply consider these direct or partial equilibrium forces. In addition, however, this paper suggests that there may exist a much more sizeable indirect or general equilibrium force that arises through housing markets and that pushes further in the direction of less private school attendance under centralization.

\subsection{The "Indirect" Effect of Centralization on Private School Attendance}

Elsewhere (Nechyba (1996, 1997a,b, 1999, 2000), Nechyba and Heise (2000)), I have argued that an analysis of fiscal federalism which ignores important general equilibrium effects may be misleading and that the limited availability of housing options within urban environments might play a significant role. ${ }^{4}$ Household choices regarding schooling are made as part of a larger choice problem in which parents choose where to live, where to send their children to school and how to vote in local and state elections, and the interaction of these choices determines housing market equilibria as well as local political equilibria. Therefore it is often difficult to think of issues such as those related to public school finance institutions without evaluating carefully the full general equilibrium in which household decisions are made.

Under local financing, for example, differences in school quality tend to cause housing prices in low income communities to be depressed and those in high income communities to be inflated. So long as desirable neighborhoods of houses exist within poor school quality districts, these capitalizations of school quality differences into housing prices may cause some

\footnotetext{
${ }^{4}$ See Bayer (1999) for evidence on the impact of limited housing options in good school districts. From a theoretical perspective, inelasticities in housing and/or the number of communities must be present in order for capitalization to take place, and the evidence suggests that such inelasticities are pervasive. The mere presence of capitalization is therefore a refutation of the full Tiebout model as any such capitalization represents opportunities for builders and community founders to make profits (Edel and Scalar (1974)).
} 
households that choose private schools to settle in such neighborhoods -- both to reduce their property tax burden and to take advantage of depressed housing values. But this capitalization will diminish under central financing as public school quality in the poor districts improves relative to the wealthier districts, and the switch to state income taxation eliminates the possibility for private school attending households to lower their tax burden by living in low school quality districts. Private school attendees who choose to live in poor districts under local public school financing in order to take advantage of depressed housing values and lower property tax payments therefore lose both these incentives under a move to centralized public school financing. Given the substantial and increasing empirical evidence that such capitalization effects exists in general, that they conform to predictions of the model employed in this paper and that voters are aware of them, it does not seem implausible that they could in fact play an important role. ${ }^{5}$

This does not, however, invalidate the insights from the Oates Decentralization Theorem -- it simply adds another dimension to an already complicated picture and thus tilts the balance away from the presumption that centralization ought to be accompanied by increases in private school attendance. While a move to state financing would cause increases in private school attendance in high income school districts precisely because of the Decentralization Theorem logic, this may be offset by both the direct partial equilibrium effect of lower private school attendance in poor districts (alluded to in the previous section) and the indirect general

\footnotetext{
5 A long literature on capitalization has evolved from Oates' (1969) seminal paper, of which Black (1999) is a recent innovative example. Nechyba and Strauss (1998) use a discrete choice model to explain residential choice based on local public finance factors. Most recently, Brunner, Sonstelie and Thayer (2000) provide evidence of voters in California's voucher initiative being driven by capitalization effects predicted by Nechyba (2000), and Reback (2000) provides evidence of similar capitalization effects in Minnesota's open enrollment program.
} 
equilibrium effect introduced here. Under the assumption that public schools use resources equally efficiently under both centralization and decentralization, it is then eminently plausible that private school attendance declines with centralization of public school financing. Furthermore, this could similarly hold for cases where centralization indeed leads to somewhat less efficient use of resources in the public sector. As a consequence, the empirical observation of little change in state-wide private school attendance after centralization has little say about the relative efficiency of resource use in centralized versus decentralized public school systems.

\subsection{Some Stylized Facts and the Plan of This Paper}

While a number of prior papers have analyzed the implication of school finance on a variety of issues, ${ }^{6}$ relatively few have investigated the impact of public school finance institutions on private school enrollments. ${ }^{7}$ A cursory look at the stylized facts across states, however, does not lend overwhelming support to the conventional wisdom that centralization (and equalization) of school finance should lead to greater private school attendance levels. Table 1 reports the number of school children enrolled in private schools as a percentage of all school children for each of the 50 states, as well as the fraction of public school funding from local sources. Abstracting from other issues (particularly the important price effects raised by Hoxby (1998)), the conventional wisdom would suggest a negative relationship between these two variables,

\footnotetext{
${ }^{6}$ See, for example, Murray, Evans and Schwab (1998), Hoxby (1998), Fernandez and Rogerson $(1998,1996)$, Fischel (1997), Benabou (1996), Sonstelie and Silva (1995), Epple and Romano (1995), to cite a few.

${ }^{7}$ Many researchers have investigated various aspects of the private/public school choice without focusing on the interactions with public school financing institutions. Recent examples of these include Downes (1996), Hoxby (1994), Hamilton and Macauley (1991) and Long and Toma (1988). Schmidt (1992) also falls into this category but presents some evidence of a link between revenue limits and private school share.
} 
with less local funding leading to higher private school enrollment. But such an effect is not immediately apparent in the data. ${ }^{8}$ Similarly, much has been written on the California experience of the 1970's when the state centralized and equalized spending on public schools. While the state experienced a sizeable growth in the number of private schools (Downes and Shane (1996)), the total percentage of children attending private schools over the next two decades increased relatively modestly. ${ }^{9}$ Little has been done in terms of theoretical work to shed light on these stylized facts - thus leaving the door open for the interpretation that these facts are only consistent with the notion that public schools do not change much under centralization.

Therefore, in order to analyze the magnitudes of various offsetting partial and general equilibrium effects inherent in school finance debates, this paper calibrates a rich theoretical model of local public school districts to data from New Jersey and simulates various types of movements from local public school financing to greater centralization. The model builds on Nechyba (1996) where the impact of different state aid formulae on local public choices and migrations is investigated in the absence of private alternatives to the local public good. I expand this framework along the lines suggested in Nechyba $(1999,2000)$ to make it particularly relevant to the school finance debate. While previous versions of the model have not been calibrated to existing private school attendance levels observed in the data, I expand the model here in order to be able to replicate important features of the data (such as private school attendance rates) more effectively. Although computationally more demanding, this expansion of

\footnotetext{
${ }^{8}$ The correlation coefficient is positive $(0.2365)$.

${ }^{9}$ Sonstelie (1979) and Sonstelie et. al. (2000) argue that the move from local to state finance had little impact on private school enrollments while Downes and Schoeman (1998) as well has Hoxby (1998) present evidence that the state's increase in private enrollments from 1970 to 1980 can at least in part be attributed to a change in public school finance regimes.
} 
the model allows me to calibrate the model explicitly to reflect current levels of private school attendance in different communities, and then to focus on the impact of changes in the school finance regime on private school enrollments, both state-wide and in particular communities.

Section 2 presents the theoretical model used in the remainder of the paper. Section 3 focuses on the calibration of the model as well as the calculation of the benchmark equilibrium that replicates the observed data. Sections 4 then turns to the main question in the paper: What happens to private school attendance when financing of public schools is moved from the local to the state level? In Section 5, I consider some other less extreme forms of centralization that involve matching and block grants in order to identify additional effects of such centralization schemes as well as to demonstrate the robustness of the main conclusion that centralization is likely to lead to declines in overall private school attendance regardless of what precise form the centralization takes. Finally, Section 6 concludes.

\section{The Model}

The theoretical model is essentially that presented in Nechyba (2000) but the computational version is extended to a significantly larger number of household types and a more empirically relevant private school sector. The model builds a private school market into a well defined local public goods economy first explored in Nechyba (1997a) and employs policy formulations previously conducted under the assumption that there are no private alternatives to the local public good (Nechyba (1996)). It takes as given the boundaries that divide a fixed set of houses into school districts and places no a priori restrictions on the mix of house and neighborhood qualities within and across these boundaries. This allows the model to 
accommodate the empirically important possibility of the coexistence of rich and poor "neighborhoods" within a single school district. ${ }^{10}$ Each household is endowed with a house (which can be sold at the market price), a parental income level and an ability level for its one child. Parents take endowments as given and choose (i) where to live, (ii) whether to send their child to the local public or a private school, and (iii) how to vote in local or state elections (depending on the finance regime that is in place) on the level of per pupil public school spending. Private schools hold an advantage over public schools in that they can set admissions requirements whereas public schools have to accept all students living within the district. A more formal exposition of these elements of the model follows.

\subsection{Community Structure and Households}

A fixed school district and neighborhood structure

$$
\mathrm{C}=\left\{\mathrm{C}_{\mathrm{dh}} \mid \mathrm{C}_{\mathrm{dh}} \cap \mathrm{C}_{\mathrm{d}^{\prime} \mathrm{h}^{\prime}}=\varnothing \forall(\mathrm{d}, \mathrm{h}),\left(\mathrm{d}^{\prime}, \mathrm{h}^{\prime}\right) \in D \times H \text { s.t. }(\mathrm{d}, \mathrm{h}) \neq\left(\mathrm{d}^{\prime}, \mathrm{h}^{\prime}\right) \text { and } \bigcup_{\mathrm{d} \in D, \mathrm{~h} \in H} \mathrm{C}_{\mathrm{dh}}=\mathrm{N}\right\}
$$

is imposed on the set of houses which is represented by the unit interval $\mathrm{N}=[0,1] \cdot{ }^{11}$ This

partitions the set of houses into a set of house/neighborhood types $H=\{1, \ldots, \mathrm{h}, \ldots, \mathrm{H}\}$ spread over a set of school districts $D=\{1, \ldots, \mathrm{d}, \ldots, \mathrm{D}\}$, where $\mathrm{C}_{\mathrm{dh}}$ is the set of houses of type h located in district

\footnotetext{
${ }^{10}$ For evidence on the empirical importance of within-district variance in house quality as opposed to acrossdistrict variance, see Epple and Sieg (1999). At the same time, however, the assumed exogeneity of the housing stock and neighborhood effects and the fixed nature of the political boundaries make the model ill suited for explaining either the evolution of observed intradistrict neighborhood structures or the formation of political jurisdictions. Instead, the model seems most appropriate for analyzing policy issues for a relatively stable and developed urban/suburban economy -- the type of economy in which capitalization effects are well documented and by themselves point to the presence of inelastic housing supplies such as those modeled here (Edel and Scalar (1974)).

${ }^{11}$ More precisely, the set of houses is defined as part of a measure space $(\mathrm{N}, \mathbb{N}, \mu)$ where $\mu$ is taken to be the Lebesgue measure. All subsets referred to are henceforth assumed to be measurable.
} 
$\mathrm{d}$, or the set of houses in "neighborhood h" of community $\mathrm{d}$. The measure of houses in district $\mathrm{d}$ is denoted $\mu\left(\mathrm{C}_{\mathrm{d}}\right)$, and the measure of houses in neighborhood $\mathrm{h}$ of district $\mathrm{d}$ is $\mu\left(\mathrm{C}_{\mathrm{dh}}\right)$.

Households are endowed with income, a house, a child with some exogenous ability level, and preferences over the consumption set. More precisely, the unit interval $\mathrm{N}=[0,1]$ which represents the set of houses also represents the set of households, and household $\mathrm{n}$ is defined to be that household who is initially endowed with house n. Furthermore, a private good endowment function $z: \mathrm{N} \rightarrow \mathbb{R}_{+}$divides this set of households into a finite set of "income types." Finally, each household $\mathrm{n} \in \mathrm{N}$ has one child, ${ }^{13}$ and ability levels for that child are assigned via a function $a: \mathrm{N} \rightarrow \mathbb{R}_{+}$(which may be correlated with household income.)

Each household $n \in \mathrm{N}$ is then assumed to act as one utility maximizing agent with utility function $u^{\mathrm{n}}: D \times H \times \mathbb{R}_{+}^{2} \rightarrow \mathbb{R}_{+}$that takes as its arguments the district and neighborhood the household lives in, its private good consumption $\mathrm{c} \in \mathbb{R}_{+}$, and the perceived school quality level $\mathbf{s} \in \mathbb{R}_{+}$enjoyed by the household's child. When choosing schools and districts, each household therefore solves the following maximization problem:

\footnotetext{
12 The assumption of finiteness of the number of income types is made for technical reasons related to the existence of an equilibrium. These issues are discussed in detail in Nechyba (1997a).

${ }^{13}$ In reality, the average number of children per household is roughly 0.5 while the assumption of a single child per household in this model fixes that average at 1. Others (Epple and Romano (1998), for instance) have handled this by assuming only half a child per household. It is unclear what the right assumption should be. A large fraction of the elderly, for instance, tend to in favor of increased public school funding for reasons that are not well understood. One interpretation of having "too many vote" children in the model is that each child "counts" for more than one household. As noted in Nechyba (2000), this causes the total spending per pupil to be too high (when the model is calibrated to replicate current per pupil spending) but it may capture the underlying behavioral parameters relevant for mobility more closely.
} 


$$
\begin{gathered}
\max _{\mathrm{d} \in D, \mathrm{~h} \in H, \mathrm{~g} \in\{0,1\}} u^{\mathrm{n}}(\mathrm{d}, \mathrm{h}, \mathrm{s}, \mathrm{c}) \text { subject to } \\
\mathrm{c}=\mathrm{p}_{\mathrm{n}}+\left(1-\mathrm{t}_{0}\right) z(\mathrm{n})-\left(1+\mathrm{t}_{\mathrm{d}}\right) \mathrm{p}_{\mathrm{dh}}-\mathrm{gT} \\
\mathrm{s}=(1-\mathrm{g}) \mathrm{s}_{\mathrm{d}}+\mathrm{gs}_{\mathrm{p}}
\end{gathered}
$$

where $g=1$ if the household chooses a private school of quality $\mathrm{s}_{\mathrm{p}}$ at tuition $\mathrm{T} ;{ }^{14} \mathrm{~s}_{\mathrm{d}}$ is the public school quality in district $d ; p_{n}$ is the market value of the house $n$ with which household $n$ is endowed; $p_{d h}$ is the price of house $h$ in district $d ; t_{0}$ is the state income tax rate; and $t_{d}$ is the property tax rate in district $d$. Since each household is infinitesimal with respect to the market, it takes all variables other than the choice variables as given (although these variables are of course all determined as part of the general equilibrium).

\subsection{Public and Private Schools}

Both public and private schools face the same technology which takes as its inputs per pupil spending as well as the peer composition of the school to produce the output $\mathrm{s}$ that enters utility functions. A child's peer quality $q^{\mathrm{n}}: \mathbb{R}_{+}{ }^{2} \rightarrow \mathbb{R}_{+}$is jointly determined by his parents' income level and his own ability. ${ }^{15}$ School quality is then given by the production function $f: \mathbb{R}_{+}{ }^{\mathrm{k}+1} \rightarrow \mathbb{R}_{+}$ that takes as its arguments per pupil spending and $\mathrm{k}$ moments of the distribution of student peer qualities. In practice, the model that is operationalized in the next section restricts itself to one moment of this distribution - the average peer quality within the school. Although public and

\footnotetext{
${ }^{14}$ Given how private school markets function in this model (as described in detail below), $\mathrm{s}_{\mathrm{p}}$ and $\mathrm{T}$ are clearly defined for each household.

${ }^{15}$ More precisely, a child is assumed to impact his peers in two ways: first, through his parents' income level and second through his own ability. The former of these captures the fact that parental involvement and monitoring of schools increases in household income (see McMillan (1999)), while the latter captures spillovers within the classroom.
} 
private schools share the same production function, they differ in three important respects: First, public schools have to accept anyone into the school so long as the household resides within the district while private schools can set minimum admission standards; second, public school funding levels are determined through a public choice process while private school spending is determined through perfectly competitive private school markets; and third, public schools are free while private schools charge tuition.

More precisely, let $\eta \subseteq N$ be the subset of households that choose to send their children to public school, and let $\mathrm{J}_{\mathrm{d}}$ be the set of households residing in school district $\mathrm{d}$. Then $\mathrm{x}_{\mathrm{d}}$ - per pupil spending in district $\mathrm{d}$-- under a system with at least some locally determined revenue is

$$
\mathrm{x}_{\mathrm{d}}=\left(\mathrm{t}_{\mathrm{d}} P\left(\mathrm{C}_{\mathrm{d}}\right)+\mathrm{AID}_{\mathrm{d}}\right) / \mu\left(\eta \cap \mathrm{J}_{\mathrm{d}}\right),
$$

where $t_{d}$ is the majority rule local property tax rate in district $d ;{ }^{16} A D_{d}$ is the total state aid received by district $\mathrm{d}$ (and funded by a proportional state income tax) determined through an exogenously specified formula; and $P\left(\mathrm{C}_{\mathrm{d}}\right)=\sum_{\mathrm{h} \in \mathrm{H}} \mu\left(\mathrm{C}_{\mathrm{dh}}\right) p\left(\mathrm{C}_{\mathrm{dh}}\right)$ is the local property tax base (which varies with the endogenously determined house price function $p: D \times H \rightarrow \mathbb{R}_{+}$that assigns a unique price $\mathrm{p}_{\mathrm{dh}}$ to each house type in each district). While voters take into account the state aid formula in their local elections, they are otherwise assumed to be myopic in that they take community composition and property values as given when going to the polls. ${ }^{17}$ Under a pure state system with no local funding, on the other hand, per pupil spending in all districts is

\footnotetext{
${ }^{16}$ Nechyba (1997b) shows that the use of property taxes is the dominant local tax strategy in this model.

${ }^{17}$ Such voter myopia is technically convenient and thus relatively standard in the literature (see Epple, Filimon and Romer (1993), Dunz (1986), Rose-Ackerman (1979)). In our case, it guarantees single peakedness of preferences in the absence of private schools (Nechyba (1997a)). To obtain single peakedness in the presence of private schools, it is also assumed that households take their private/public choice as given when voting on public school spending. While this results in the existence of equilibria where no public schools are funded, the simulations ignore such equilibria unless they are the only ones generated by the model. For more details, see Nechyba (1999).
} 
equalized and funded by a state majority-determined income tax rate $\mathrm{t}_{0}-\mathrm{i}$.e.

$$
\mathrm{x}_{\mathrm{d}}=\mathrm{x}=\left(\mathrm{t}_{0} z(\mathrm{~N})\right) / \mu\left(\eta \cap \mathrm{J}_{\mathrm{d}}\right), \forall \mathrm{d} \in D
$$

Finally, peer composition in public schools is simply determined by the characteristics of the households that reside in the district and choose not to use a private school $\left(\mu\left(\eta \cap J_{d}\right)\right)$.

In contrast, private schools are assumed to choose admissions standards (thus explicitly restricting access) and tuition rates so as to maximize profit in a perfectly competitive private school market. Each private school therefore announces two characteristics: the tuition rate that is charged per child, and the minimum peer quality accepted into the school. ${ }^{18}$ Given that there are no set-up costs or increasing returns in the production technology $f$ faced by private schools, it is then immediate that all parents whose children attend a particular private school must be of the same endowment and peer type in equilibrium and that they pay tuition that is exactly equal to their most preferred level of per pupil spending. ${ }^{19}$ This, then, is the source of the competitive advantage of the private over the public sector: it offers spending levels that may be more in line with particular household preferences, and it takes advantage of peer contributions to education output by excluding peer qualities below some minimum standard. In equilibrium, private schools are thus quite heterogeneous across schools but homogeneous within any given school.

\footnotetext{
${ }^{18}$ Note that, for technical reasons in part exposited in Nechyba (1999), this differs from the model of Epple and Romano (1998) in which schools discriminate in their tuition policies.

${ }^{19}$ Suppose, for a moment, that this were not the case. In particular, suppose that a private school provided education to children of two different income types. Then a new school that offered admission only to the higher income type (at the same tuition) would improve the utility of the higher income parents (because of the higher overall peer quality achieved through selective admissions). Under free entry, such a school would in fact arise. Similarly, free entry eliminates all tuition levels other than those most preferred by parents. For a formal proof of this, see Nechyba (1999).This is similar to the familiar logic that underlies the Hamilton (1975) local public finance result that zoning results in homogeneous communities. In that model, communities (rather than private schools) fix a local tax/spending package (analogous to tuition levels) and set a minimum zoning (rather than peer quality) level. Nechyba (1999) also pointed out that the assumptions made here are formally equivalent to treating private schools as excludable clubs under an equal cost sharing rule.
} 


\subsection{Equilibrium}

An equilibrium in this model consists of a list $\{\mathrm{J}, \mathrm{t}, \mathrm{s}, \mathrm{p}, \eta\}$ that includes a partition of households into districts and neighborhoods $\mathrm{J}$, state and local tax rates $\mathbf{t} \in \mathbb{R}_{+}{ }^{\mathrm{D}+1}$ (where $\mathrm{t}_{0}$ is the state income tax rate and $t_{d}$ is the property tax rate in district $\left.d \in D\right)$, local public school qualities $\mathbf{s} \in \mathbb{R}_{+}{ }^{\mathrm{D}}$, house prices $\mathbf{p} \in \mathbb{R}_{+}{ }^{\mathrm{DH}}$ and a specification of the sub-set of the population that attends public rather than private schools $\eta \subseteq N$. It can be defined formally as follows:

Definition: An equilibrium is a list $\{\mathbf{J}, \mathbf{t}, \mathbf{s}, \mathbf{p}, \eta\}$ such that

(1) $\mu\left(\mathrm{J}_{\mathrm{dh}}\right)=\mu\left(\mathrm{C}_{\mathrm{dh}}\right) \forall(\mathrm{d}, \mathrm{h}) \in D \times H$ (every house is occupied);

(2) Property tax rates $\left(t_{1}, \ldots, t_{D}\right)$ are consistent with majority voting by myopic residents, and the state income tax rate $t_{0}$ is sufficient to cover the aid to public schools;

(3) $s_{d}=f\left(x_{d}, q_{d}\right)$ for all $d \in D$, where

$$
\begin{aligned}
& \mathrm{x}_{\mathrm{d}}=\left(\mathrm{t}_{\mathrm{d}} P\left(\mathrm{C}_{\mathrm{d}}\right)+\mathrm{AID}_{\mathrm{d}}\right) / \mu\left(\eta \cap \mathrm{J}_{\mathrm{d}}\right)(\text { budgets balance) and } \\
& \mathrm{q}_{\mathrm{d}}=\left(\int_{\mathrm{n} \in \eta \cap \mathrm{J}_{\mathrm{d}}} q(\mathrm{n}) \mathrm{dn}\right) / \mu\left(\eta \cap \mathrm{J}_{\mathrm{d}}\right) \text { (average peer quality within public school); }
\end{aligned}
$$

(4) At prices $p$, households cannot gain utility by moving and/or changing schools;

(5) Each household is able to choose a private school that offers its own peer group and charges the household's most preferred tuition (that equals per pupil spending within the school) -- i.e. private school markets are perfectly 
competitive.

For a thorough discussion of existence and uniqueness properties of this equilibrium, see Nechyba (1997a, 1999, 2000).

\section{Calibration to the Benchmark Equilibrium}

The calibrated computable general equilibrium (CGE) model used in the policy simulations of Sections 4 and 5 sets $\mathrm{H}=5$ and $\mathrm{D}=3$. This implies the existence of 15 different neighborhoods spread over 3 school districts. The school districts are of equal size (i.e. $\left\{\mu\left(\mathrm{C}_{1}\right), \mu\left(\mathrm{C}_{2}\right), \mu\left(\mathrm{C}_{3}\right)\right\}=$ $\{1 / 3,1 / 3,1 / 3\})$ as are the neighborhoods within districts (i.e. $\left.\mu\left(\mathrm{C}_{\mathrm{dh}}\right)=1 / 15 \forall(\mathrm{d}, \mathrm{h}) \in D \times H\right)$. These districts are intended to be representative of the several hundred low income, middle income and high income school districts located in 4 New Jersey counties (Bergen, Hudson, Essex and Union Counties) that include the suburbs of New York City.

\subsection{Data used for Calibration}

More specifically, using 1990 School District Data Book (National Center for Education Statistics (1995)) and Census (Bureau of the Census (1992)) data from all districts in these four counties, school districts in these four counties were divided into three categories by median household income such that each category ended up with roughly equal numbers of households. Table 2 gives summary statistics for each class of districts. From price data on houses in the various district types I am able to infer neighborhood quality parameters that enter directly into utility functions by a process described in detail in Section 3.5. For now I simply note that this 
calibration translates a near-continuum of house qualities observed for each district type into 5 discrete quality intervals (neighborhoods) of equal sizes. More precisely, one fifth of all houses in district $\mathrm{d}$ are assigned the house/neighborhood quality of the median house observed in the data for that district and are labeled houses of neighborhood type $\mathrm{h}=3$. Similarly, neighborhoods 2 and 4 represent "somewhat below average" and "somewhat above average" house qualities

respectively, and one fifth of all houses within district $d$ are assigned quality levels corresponding to those observed at the $30^{\text {th }}$ and $70^{\text {th }}$ quality percentile for that district type. Finally, neighborhoods 1 and 5 represent the worst and best houses in a particular district, and one fifth of all houses in district $d$ are assigned the quality level observed for the houses in the $10^{\text {th }}$ and $90^{\text {th }}$ percentile (respectively). Note that when I employ price data to calibrate house qualities within districts, I capture both characteristics of the houses and characteristics of the neighborhoods in one measure. Thus, the model allows for both neighborhood externalities and amenities as well as house qualities to determine the character of neighborhoods (or house types) within school districts.

\subsection{Endowments and Preferences}

The income endowment function $z: \mathrm{N} \rightarrow \mathbb{R}_{+}$chosen for the CGE model creates 20 income types and replicates a discretized version of the actual household income distribution observed for the New Jersey districts used in the calibration. Incomes in the model therefore range from 1 (corresponding to $\$ 10,000$ ) to 20 (corresponding to $\$ 200,000$ ), and the measure of agents with different levels of income is given by the observed household income distribution in the data. It 
should be kept in mind that this eliminates from the model extremely poor and extremely wealthy households by truncating the income distribution at 1 and 20. Given that it is likely that such extreme households are often motivated by factors quite different from the middle class (broadly defined), however, this appears to be a minor limitation of the model.

Each of the 20 income types is initially spread uniformly across all neighborhoods (in all school districts) when house endowments are assigned. Given that this is a static model calibrated to annual data, the "value" of a house is defined as the annualized flow of housing/neighborhood services from that house. Furthermore, it is important to note that, while some low income households are endowed with high quality houses, this does not imply that these low income households actually live in high priced houses in equilibrium. The endogenously determined value of these endowments (i.e. the value of the annual flow of services from these endowments) falls between 0.3 and 3.5 and thus simply serves to smooth out the discretized income distribution by adding an endogenously determined component to the exogenous income endowment for each household. This causes the initial set of 20 income types to become 300 endowment types.

In the CGE model, ability levels take on 5 different possible discrete values which are set to range from 1 to 10$).{ }^{20}$ Empirical estimates of the correlation of parental and child income of 0.4 (Solon (1992), Zimmerman (1992)) are used as a proxy for the correlation of parental income and

\footnotetext{
20 These values are admittedly arbitrary, but sensitivity analysis has shown that changing either the mean or variance of these numbers has little qualitative or quantitative impact on the results presented in this paper.
} 
child ability; ${ }^{21}$ i.e. I assign the five ability levels in equal measure but distribute them in such a way as to make the correlation between parental income and child ability equal to 0.4 . Given the 300 endowment types specified above, this addition of ability levels generates a total of 1,500 types.

To avoid problematic multiplicity of equilibria (Nechyba (1999)), I assume a single utility function that applies to all households:

$$
u^{\mathrm{n}}(\mathrm{d}, \mathrm{h}, \mathrm{s}, \mathrm{c})=\mathrm{k}_{\mathrm{dh}} \mathrm{s}^{\alpha} \mathrm{c}^{\beta} \forall \mathrm{n} \in \mathrm{N} .
$$

The determination of $\mathrm{s}$ is explored next, and the calibration of $\left\{\mathrm{k}_{\mathrm{dh}} \mid \mathrm{d} \in \mathrm{D}, \mathrm{h} \in \mathrm{H}\right\}, \alpha$ and $\beta$ is described in Section 3.5.

\subsection{Production Function for School Quality}

Household peer quality is given by $q(\mathrm{n})=\left(z(\mathrm{n})^{\theta} a(\mathrm{n})^{(1-\theta)}\right) / 7.5 .^{22}$ Thus, as $\theta$ increases, the importance of parental income increases while that of child ability declines. One possible interpretation of this is that $\theta$ represents the degree to which peer effects work through the channel of parental monitoring as opposed to the child's inherent ability. Letting $\mathrm{x}$ be equal to per pupil spending and q be equal to average peer quality, household choices are then assumed to be made as if the school production function were accurately described by the constant returns to scale process:

\footnotetext{
${ }^{21}$ One can also interpret the correlation between parental and child income of 0.4 as an upper bound on the correlation between parental income and child ability because of the correlation of school quality and parental income. Sensitivity analysis with versions of the model that drive the correlation to 0 , however, suggest this makes little difference for the results I report.

22 The function is divided by 7.5 in order to make peer quality similar in magnitude to per pupil spending. This is of no consequence other than that is eases the interpretation of the parameter $\rho$ in the next equation.
} 


$$
\mathrm{s}=f(\mathrm{x}, \mathrm{q})=\begin{aligned}
& 0 \text { if } \mathrm{x}<0.5 \\
& \mathrm{x}^{1-\rho} \mathrm{q}^{\rho} \text { otherwise }
\end{aligned}
$$

Thus, a minimum per pupil spending level of 0.5 (i.e. $\$ 5,000$ ) is required for a school to function, and school quality is determined as a combination of per pupil spending and average peer quality. The minimum per pupil spending requirement adds some realism to the public choice process in that it does not permit majorities who attend private schools to implement their preferred level of zero spending on public education, and it thus prevents simulations from finding trivial equilibria in which no public schools exist (Nechyba $(1999,2000))$. As will be seen shortly, the requirement is not a binding constraint in the benchmark equilibrium that replicates the New Jersey data in which all districts choose to spend more than $\$ 5,000$ per pupil, but it does become a binding constraint under the hypothetical scenario of pure local financing.

Note that so long as $\rho<1$, this implies that additional material resources (x) are viewed by parents as translating directly into gains in school quality. As noted in my previous work, this does not mean that the model necessarily takes a position in the ongoing debate over the role of school resources in the production of outcomes like test scores. ${ }^{23}$ Rather, this model attempts to predict changes in parental choices as state financing regimes are changed, and, if parents think school resources matter for whatever reason, then this must be included in the analysis. It seems uncontroversial to say that there is in fact overwhelming evidence that per pupil spending does affect parental location and voting choices and thus does matter to parents. In fact, as will

\footnotetext{
${ }^{23}$ Debate over this continues, as demonstrated by the recent work of Card and Krueger (1992), Betts (1996), Heckman, Layne-Farrar and Todd (1996), Barro and Lee (1997), Hanushek (1999) and Krueger (1999).
} 
become clear below in the discussion of the calibration of $\theta$ and $\rho$, the model cannot replicate the observed mix of public and private schools unless both peer quality and per pupil spending are viewed as important by parents. This calibration is left to Section 3.5.

\subsection{State Aid in New Jersey}

The CGE model contains state aid levels corresponding to those found in the representative districts in New Jersey in 1990. However, it is unclear from merely looking at state aid formulae to what extent aid is given in matching or block form. As I discuss elsewhere (MaCurdy and Nechyba (2000)), a variety of political and fungibility questions obscure the actual aid transmission mechanism. For this reason, I constrain total state aid to each community to be equal to what is observed in the data, but I adjust the degree of matching versus block aid somewhat from district to district to more closely calibrate the actual spending levels that arise out of the political process. This requires a slight negative match rate in district 3 and a substantial positive match rate in district 1.

\subsection{Calibration of Remaining Parameters}

Having specified the calibration of incomes and endowments, I now turn to the remaining preference and production function parameters. On the preference side, house quality parameters $\left\{\mathrm{k}_{\mathrm{dh}} \mathrm{d} \in \mathrm{D}, \mathrm{h} \in \mathrm{H}\right\}$ as well as the Cobb-Douglas exponents $\alpha$ and $\beta$ remain to be specified, as do $\rho$

and $\theta$ on the production side. This section details the methodology by which these parameters are chosen. The values themselves are summarized in Table 3.

The general strategy for a large part of this calibration is similar to that laid out in Nechyba 
(1997b, 2000). I assume an underlying utility function $u(\mathrm{~h}, \mathrm{~s}, \mathrm{c})=\mathrm{h}^{\delta} \mathrm{s}^{\alpha} \mathrm{c}^{\beta}$ where $\mathrm{h}$ jointly captures housing and neighborhood quality and is interpreted as the annualized flow of housing/ neighborhood services. Given that $\mathrm{s}$ is determined in a Cobb-Douglas production process that places weight $(1-\rho)$ on per pupil spending $x$, we can re-write this utility function as

$$
u(h, x, c ; q)=h^{\delta}\left(x^{(1-\rho)} q^{\rho}\right)^{\alpha} c^{\beta}=\gamma h^{\delta} x^{(1-\rho) \alpha} c^{\beta}
$$

where $\mathrm{q}$ is equal to peer quality and $\gamma=\mathrm{q}^{\rho \alpha}$. When treating $\mathrm{h}$, $\mathrm{x}$ and $\mathrm{c}$ as choice variables in an ordinary maximization problem, the exponents $\delta,(1-\rho) \alpha$, and $\beta$ can then, without loss of generality, be normalized to sum to 1 and interpreted as budget shares. Thus, I calculate the budget shares for $\mathrm{h}, \mathrm{x}$ and $\mathrm{c}$ for a hypothetical "median household" that consumes the imputed median annualized flow of housing/neighborhood services (in the data), earns the median income and "chooses" the mean school spending level observed in the New Jersey districts, and I interpret these as $\delta,(1-\rho) \alpha$, and $\beta$ (equal to $0.22,0.12$ and 0.65 respectively). ${ }^{24}$

Of course, housing in the model is not a continuous variable $\mathrm{h}$ but rather consists of a discrete number of house/ neighborhood quality levels $\left\{\mathrm{k}_{\mathrm{dh}} \mid \mathrm{d} \in \mathrm{D}, \mathrm{h} \in \mathrm{H}\right\}$. I therefore combine the housing value distribution data from the School District Data Book with my estimate for $\delta$ to calibrate the fifteen values for $\mathrm{k}_{\mathrm{dh}}$ across the three representative school districts. In particular, I take the housing distribution for all houses in districts of a particular type (i.e. low, middle or high income as defined above), find house values at the $10^{\text {th }}, 30^{\text {th }}, 50^{\text {th }}, 70^{\text {th }}$ and $90^{\text {th }}$ percentile (corresponding to neighborhoods 1 through 5 in district 1) and convert these to annualized housing flows (using a 5\% interest rate). I then combine these annualized flow values with the

\footnotetext{
24 Given data on house prices rather than flows of housing services, the median annualized flow of housing/neighborhood services is calculated for the median house value in the data assuming a 5\% interest rate.
} 
exponent $\delta$ to arrive at the five housing (or neighborhood) quality parameters for this representative district. More precisely, suppose that for houses in districts falling into district category 3 (i.e. "high income districts"), the annualized flow of housing services for a house at the $50^{\text {th }}$ percentile of the distribution is 1.5 (corresponding to $\$ 15,000$ ). The housing quality parameter for neighborhood 3 (the "median neighborhood") in district 3 is then just equal to $(1.5)^{\delta}$, i.e. $\mathrm{k}_{23}=(1.5)^{\delta}=(1.5)^{0.22}=1.093$. This procedure is then similarly applied to other district types to arrive at housing quality parameters for all neighborhoods in all representative districts. These parameters are reported in Table 3. One small caveat is that, for purposes of identifying the size of capitalization effects clearly, one house quality level appears in all three communities: i.e. $\mathrm{k}_{13}=\mathrm{k}_{22}=\mathrm{k}_{31}$.

While housing quality parameters as well as the exponent $\beta$ have thus been determined, the values for $\alpha, \rho$ and $\theta$ remain ambiguous. With respect to $\theta$, I know of no consistent and reliable estimates from past work that can be helpful in determining the impact of parental socioeconomic status relative to child ability in determining peer externalities. However, in prior work (Nechyba (2000)), I have argued that the precise value of $\theta$ has little bearing on many results, and this is similarly true in the present context. I therefore set $\theta$ to $0.5^{25}$. This leaves only $\alpha$ and $\rho$, and the calibration procedure above has placed a restriction on these values given that $(1-\rho) \alpha$ is interpreted as the budget share of school spending for the median in the data. Again, there is little in the data or in prior empirical work that can be used to assign precise values to $\rho$ and $\alpha$. However, if $\rho$ is set close to 0 (i.e. if school quality is determined primarily by spending

\footnotetext{
${ }^{25}$ Sensitivity analysis surrounding this parameter goes unreported here but is available upon request.
} 
levels rather than peer quality), private schools do not emerge in the model (even if private schools are heavily subsidized). Similarly, if $\rho$ is set too close to 1 (i.e. if school quality is determined primarily by peer quality and not by spending), public schools cannot exist in equilibrium (even without private school subsidies). The level of $\rho$ can then be set so as to yield the equilibrium level of private school attendance I observe in New Jersey. Note that this allows for private school attendance rates in the benchmark equilibrium to reflect those observed in districts 1 and 2, but the model has difficulty simultaneously replicating the actual private school attendance rates in district 3 .

\subsection{Benchmark Equilibrium}

Table 4 gives a benchmark equilibrium for the New Jersey data. Note that per pupil spending levels as well as mean incomes closely mimic those found in the representative districts reported in Table 1. Although not shown in the table, interjurisdictional differences and overlaps in housing prices are also similar to those found in the data, both for representative districts and for actual sample districts in New Jersey. While this benchmark equilibrium is based on a replication of the state aid programs in New Jersey, it is worth noting that these programs are used only for calibration purposes. From here on out, the parameters that have been produced through this calibration technique are taken as given, but the public school financing mechanisms are altered in order to investigate the role of such institutions in a world in which the underlying preference, endowment and production parameters are consistent with what is observed in the New Jersey data. 


\section{Pure Local versus Pure State Financing}

I begin by comparing results from pure local and pure state financing systems. Recall that under pure local financing, local (proportional) property tax rates are set by the voters of each school district, and all tax revenues are spent within the district. Under state financing, on the other hand, state (proportional) income taxes are set by voters in the whole state and distributed equally (on a per pupil basis) to all districts. Table 5 reports a variety of school related variables such as the percentage of residents in each district that choose private schools, the per pupil spending levels in each district and the public school quality (as defined above) under these two public finance regimes. Furthermore, the table reports average property values, and it compares the combined cost of property taxes and house payments faced by households choosing the house type $\left(\mathrm{k}_{\mathrm{mh}}=0.93\right)$ that exists in all three communities.

The most obvious feature of the table is that, counter to the conventional wisdom, the overall percentage of parents choosing private schools is slightly lower under state financing than under local financing, with districts 1 and 2 experiencing a decline in private school attendance and district 3 experiencing an increase. A closer inspection of the full simulation results reveals the underlying forces at work. First, public school quality in district 1 increases due to the substantially higher level of per pupil spending under state financing, and public school quality in district 3 declines for analogous reasons. This clearly leads to the direct effect of less private school attendance in the poor district and greater private school attendance in the rich district assuming all else (including residential location) remained the same. Second, while average property values change little, the opportunity cost of choosing certain houses in district 1 increases dramatically which then sets off the indirect effect that leads private school attendees 
who previously chose district 1 because of lower housing costs to move to other districts.

The latter indirect effect is not immediately transparent. First, recall that state income tax obligations are the same for a given household regardless where that household resides. State income taxes are therefore sunk costs when households make residential location choices. Under local financing, on the other hand, property tax bills differ depending on where one lives, and so the price that is relevant for the households when making residential location choices under local financing is the property tax-inclusive house price. The last two columns of the table present the property tax inclusive price for a house of the same quality $\left(\mathrm{k}_{\mathrm{mh}}=0.93\right)$ located in the three different districts. The ratio of the price of residing in such a house in district 1 to that of residing in the same house in district 3 is 0.45 under local financing but jumps to 0.63 under state financing -- a 40 percent increase. As it turns out, this house is inhabited in part by private school attending households with relatively low incomes but high ability children under local financing but not under state financing. As the opportunity cost of residing in this house increases under state financing, these households move to similar houses in other districts and attend public schools. $^{26}$

Two distinct causes for the drop in private school attendance under state financing therefore emerge. First, of those residing in district 1 under both financing regimes, marginal private school attendees under local financing may switch to public schools due to the increased quality of such schools (the direct effect). Second, local financing embeds a substantial incentive for

\footnotetext{
${ }^{26}$ For this house, even the before tax price rises under centralization as the higher school quality is capitalized. (This is obvious from noting that even the after tax price has increased.) Since average before tax house prices in district 1 fall under centralization, this implies that some before tax house prices in district 1 must be falling. As it turns out, capitalization effects within districts can be quite different within a district given the multiple factors that shift demand for various types of houses.
} 
private school attendees to trade off some house quality to live in the substantially cheaper but still acceptable neighborhoods of district 1 when sending their children to private schools. Under state financing, on the other hand, tax-inclusive prices for such houses rise substantially relative to similar houses in other districts, thus decreasing the incentive for families to accept lower quality housing in district 1 when choosing private schools (the indirect effect). Some private school attendees in district 1 under local financing may therefore choose to reside in other districts under state financing. Of the decline in private school attendance in the poor district under state financing, two thirds is due to out-migration of precisely such families, while the remaining one third consists of high ability households who switch to the improved local public school. ${ }^{27}$ The indirect general equilibrium effect in the simulations is therefore quite significant.

In district 3 , on the other hand, private school attendance rises for exactly analogous reasons. First, public school quality under state financing is lower due to less per pupil spending. This may cause marginal public school attendees under local financing to switch to private schools under state financing. Second, housing has become relatively cheaper (in terms of the relevant opportunity costs) in district 3, causing some private school attendees from other districts to immigrate. In the simulations, roughly half of the increase in private school attendance in district 3 occurs among populations that reside in that district under both finance systems (direct effect), while the remaining increase is due to migration (indirect effect).

Furthermore, it should be noted that the impact on private school attendance seems primarily due to centralization itself and not due to a switch from property taxation (under local

\footnotetext{
${ }^{27}$ More precisely, when utility levels of private school attendees residing in district 1 under local financing are compared to utility levels assuming they went to public schools of quality equal to that under state financing, only one third of households from these private schools would switch to the higher quality public schools.
} 
funding) to income taxation (under state funding). To verify this, I have run an additional simulation under which the state imposes a property tax uniformly across all districts and uses it to fund all public schools at equal per pupil spending levels. The overall private school attendance under this simulation is $18.33 \%$, exactly equivalent to what is reported under a state administered income tax in Table $5 .^{28}$ (The results in the next section are also not very sensitive to the assumption of state income rather than state property taxation.)

While the focus of the paper is clearly to understand how partial and general equilibrium predictions of private school attendance differ, a few other features of Table 5 are noteworthy. First, per pupil public school spending drops as the system moves from one of local to one of state financing. This arises primarily from the well understood effect of the skewedness of the state income distribution as demonstrated in Sonstelie and Silva (1995). ${ }^{29}$ Second, the decline in the average public school quality that accompanies centralization in Table 5 is almost entirely

\footnotetext{
${ }^{28}$ Just as under state income taxation, the equalization of spending across districts causes public school quality differences to narrow, with public school quality rising to 0.4548 in district 1 and falling to 0.7153 in district 3. An important difference with state income taxation, however, is that property taxes are relevant for the housing decision even when rates are equalized across districts (while income tax rates are not). This is because under a state property tax system, a household's actual tax payment does depend on which house the household owns, while the same is not true for state income tax payments. Since housing prices in district 1 are lower than elsewhere, this makes district 1 ceteris paribus more attractive under state property taxation than under state income taxation which implies that property values in equilibrium will tend to be relatively higher in district 1 under state property taxation than under state income taxation. The converse holds in district 3 . This is borne out in the simulations, where average property values in district 1 are 0.7253 under state property taxation (as opposed to 0.6177 in Table 5), and average property values in district 3 are 1.4555 (as opposed to 1.6490 in Table 5). The indirect effect referred to in the discussion of state income taxes is therefore more transparent in the case of state property taxes because the entire effect can be seen in property values themselves (rather than a combination of property values and relevant tax payments). Finally, while the overall rate of private school attendance happens to decline by the same magnitude regardless of whether the state equalizes expenditures through state income or state property taxes, the distribution of private school attendance across districts differs slightly between the two simulations. In particular, under state property taxation the private school attendance rates are $25 \%, 17.5 \%$ and $12.5 \%$ for districts 1 through 3 , as opposed to $22.5 \%, 17.5 \%$ and $15 \%$ under state income taxation (Table 5).

${ }^{29}$ Under the median voter hypothesis, as one moves from local to state financing the determining factor for average per pupil spending moves from the mean to the median of the income distribution. Since the mean lies below the median, spending is predicted to fall.
} 
due to the decline in average per pupil spending and not at all because public schools use resources less efficiently under centralization (which is assumed away in this model). ${ }^{30}$ An assumption of a decline in public school efficiency with centralization could clearly be built into the model, and for modest declines in efficiency, private school attendance still declines with centralization. As public schools are assumed to be increasingly less efficient with centralization, of course, private school attendance eventually does increase when financing of public schools is moved from the local to the state level. Thus, the model suggests that the empirical observation of little response of private school attendance rates to centralization and equalization of public school financing cannot be taken as evidence that school resource efficiency remains unchanged. Rather, any empirical observation of an increase in private school attendance following centralization of public school financing is much more suggestive of declines in public school efficiency when viewed in a general equilibrium context than when viewed from a partial equilibrium analysis, and even a decline in private school attendance following centralization does not rule out a decline in public school efficiency.

\section{Centralization with Local Discretion}

Above, I have analyzed the two extremes - pure local and pure state financing. Virtually all public school finance systems in the US, however, fall somewhere between these extremes. This section therefore explores how the general equilibrium forces identified in Section 4 translate into predictions for hybrid state/local public school funding. In particular, while the previous

\footnotetext{
${ }^{30}$ A small portion of the change in public school quality is also attributable to a change in the peer composition in the public schools.
} 
section focused on a particular type of centralization of public school financing, we now turn to more common types of central government involvement that involve block and matching grants combined with local discretion. The conclusion from this analysis is that private school attendance will drop much more significantly under centralization policies that allow for local discretion, in large part because high income communities can maintain high levels of public spending under such state policies (and thus do not experience the direct effect of an increase in private school attendance). Additional declines in private school attendance can also arise from price (substitution) effects inherent in some types of state aid formulae. Therefore, the modest and counterintuitive decline in private school attendance from centralization observed in the previous section (where centralization allowed for no local discretion and included no price effects) represents a lower bound on the decline in private school attendance that can accompany centralization policies.

I will differentiate hybrid systems of state/local public financing along two dimensions. First, state aid formulae may or may not differentiate between districts based on district wealth, and second, aid to local school districts may take either the form of matching or block aid. In all cases I will assume that state aid is financed through the levy of a statewide (proportional) income tax. Matching and block aid is defined as in Nechyba (1996), with matching grant programs characterized by a vector $\mathbf{m}=\left(\mathrm{m}_{1}, \mathrm{~m}_{2}, \mathrm{~m}_{3}\right)$ indicating the rate at which local funds are matched in each of the three school districts, while a block grant program is defined by $\mathbf{b}=\left(\mathrm{b}_{1}, \mathrm{~b}_{2}, \mathrm{~b}_{3}\right)$ indicating the per pupil level of state aid provided to each district. A state program $\mathbf{m}=(0.5,0,0)$, for instance, indicates that the state matches every dollar in local funds by 50 cents in district 1 and not at all in districts 2 and 3 , while a program $\mathbf{b}=(0.1,0.1,0.1)$ indicates a block 
grant of 0.1 (or $\$ 1,000)$ per pupil to all districts. I will call a state grant program "un-targeted" or "universal" if it does not discriminate between districts; i.e. if $\mathrm{m}_{1}=\mathrm{m}_{2}=\mathrm{m}_{3}$ and $\mathrm{b}_{1}=\mathrm{b}_{2}=\mathrm{b}_{3}$.

Below, I begin the analysis with universal block grants, then proceed to discuss universal matching aid and finally turn to aid specifically targeted to poor districts. In addition to the direct and indirect effects identified in the previous section for centralization through a state take-over, block grants give rise to a third "local discretion" effect, and matching grants add yet a fourth "price subsidy" effect. Each of these effects leads to a greater overall decline in private school attendance when grants are not targeted. When they are targeted, a similar conclusion follows for grants that are sufficiently large to be binding in that they affect local public finance decisions.

\subsection{Universal State Block Aid and the "Local Discretion" Effect}

The first part of Table 6 focuses on results from introducing universal block grants. These types of grants share in common some of the same forces that were important in a switch from local to state funding of education, but they also contain some rather different incentives which lead to some additional effects. In particular, state income taxes are used to substitute for a large part of local property taxes under both state financing and block grant financing, and thus both types of centralization cause tax payments to become less dependent on district choice. At the same time, large block grants differ from pure state financing in that they permit local districts to supplement state aid with local property taxes and thus to differ in their per pupil spending from other districts. This results in a combination of effects that, on balance, cause larger declines in private school attendance overall.

More precisely, because an increasing fraction of public schools are funded through the 
state income tax, tax-inclusive house payments in district 1 rise relative to those in districts 2 and 3 even though property values themselves fall -- just as in the case of state financing. Private school attendance in district 1 then declines with increasing block grants primarily because private school attending parents choose to migrate out of district 1 as relative prices rise -- an effect again similar to what was observed in Section 4 for state financing. When block grants in district 1 become binding; i.e. as the block grant causes large increases in local public school spending, the public schools in district 1 gain substantially in quality, thus causing further declines in private school attendance -- but now not merely from migration. This again is similar to the effects observed under a move to state financing. An important difference, however, arises in district 3 where, contrary to what is permitted under the state takeover, the high income district can supplement the block grant with local property taxes. Centralization through block grants therefore embeds local discretion for higher income districts which in turn causes private school attendance in those districts to decline rather than increase. This in turn mutes the general equilibrium effects in that the tax inclusive decline in the relative price of living in district 3 rather than district 1 is less pronounced (because house prices in district 3 still capitalize the higher spending on public schools in that district.) Thus, block grants give rise to a smaller decline in private school attendance in district 1 than occurs under state financing, but this smaller decline is not offset by in increase in private school attendance in district 3 (as happens under state financing) because of the local discretion that is preserved under block grants but not under pure state financing. The combination of the direct and indirect effects at work in district 1 with the "local discretion" effects in district 3 then causes private school attendance rates on balance to decline more under centralization through block grants than under centralization 
through a state takeover.

\subsection{Universal State Matching Aid and the "Price-Subsidy" Effect}

The second part of Table 6 provides simulation results for universal matching programs. As is well understood, the pure income effect of block grants is substantially weaker at stimulating local public spending than the combination of income and price effects embedded in matching aid. Increases in public school spending under matching aid are therefore significantly larger than those observed in the first portion of Table 6 for block grants, and the decline in private school attendance is correspondingly faster.

Note that in almost all cases, matching aid results in increases of school spending (as expected), with the exception of low matching rates in district 1 . The latter anomaly is due to the assumption that a minimum of $\$ 5,000$ in per pupil spending is required for schools to operate, and it makes low levels of matching aid in district 1 equivalent to small block grants that are passed on to residents through local property tax cuts. Ceteris paribus, a matching grant of 0.2 is thus equivalent to a block grant of 0.0844 for district 1 . However, because even a matching grant of 0.2 leads to substantial increases in school spending in districts 2 and 3, a large drop in district 1 's private school attendance is observed as previous high ability private school attendees migrate to districts 2 and 3 to attend public schools. In fact, the entire drop in district 1's private school attendance for low levels of universal matching aid results from such migration.

Once matching aid rises above a critical level, public school spending and quality rise in all districts, accompanied by declines in private school attendance. Unlike for the case of low matching aid, however, an increasing portion of the remaining drops in private school attendance 
results from residents of each district switching from private schools to public schools -- and a declining portion results from the migration effects identified above. Throughout, property values in district 1 decline relative to property values in other districts because of the decline in demand for housing in the poor district by households desiring private schools for their children. It is clear, however, that centralization through universal matching aid not only leads to declines in private school attendance but eventually, because of the increasingly large price subsidies that induce districts to raise per pupil spending, to the complete vanishing of all private schools (as matching rates in the public sector rise high enough). Centralization through matching grants is therefore accompanied by much larger declines in private school attendance than centralization through a state take-over or through block grants. This decline is now due to (i) the direct and indirect effects identified for the previous two forms of centralization, (ii) the "local discretion" effect identified for block grants and (iii) the price-subsidy effect unique to matching grants.

\subsection{Targeted State Aid}

Finally, Table 7 reports simulation results involving matching and block grants targeted only to district 1 . Again, the top portion of the table begins with block grants, and the lower portion proceeds with different levels of matching grants. However, this time no grants are provided to other districts, leaving public school spending there relatively unchanged and causing property values in district 1 to rise relative to those in districts 2 and 3 . Since property taxes in district 1 decline, however, tax inclusive property values in district 1 relative to those in districts 2 and 3 are unchanged, which implies that the general equilibrium (indirect) effects pointed to in all previous cases are largely absent for targeted grants. Thus, targeted grants are the first form of 
centralization that do not give rise to the counterintuitive effect highlighted in this paper.

More specifically, for block aid levels that do not bind (i.e. aid levels below $\$ 5,000$ ), per pupil public school spending in district 1 remains unchanged, and local taxes are reduced as state aid increases. Property values therefore rise not because of an improvement in public schools, but rather because local property taxes decline - thus leaving tax inclusive property values essentially unchanged relative to those in other districts. While this precludes a significant general equilibrium effect, it does lead to income effects for households in district 1 as local property taxes are replaced by state income taxes (largely paid by residents of districts 2 and 3). These income effects in turn cause some marginal public school attending households in district 1 to switch to private schools. Since the marginal public school attendees are of high peer quality, this then causes a decline in public school quality (as average peer quality in the public school declines), thus causing an additional increase in private school attendance that would not have occurred had public school quality remained unchanged. Since nothing of significance happens in the remaining districts, low levels of targeted block aid therefore lead to an overall increase in private school attendance (from 20 percent to roughly 23 percent). The decline in district 1 private school attendance that we have come to expect from the previous tables then only occurs as the block grant begins to bind (in the sense that public school spending in the district rises). Private school attendance then also falls modestly in other districts as some marginal households move to district 1 due to the improvements in public school quality.

As noted in the previous discussion on matching grants, low levels of such grants are in fact equivalent to block grants in the poor community. Thus, for low levels of matching aid ( $\mathrm{m}=0.2$ is roughly equivalent to $b=0.0844$ ) in the second part of Table 7 , effects precisely analogous to 
those for block grants occur. However, as matching grants become larger and the price subsidy effect kicks in, private school attendance begins to decline as public school quality increases in

district 1 . For both targeted block and matching aid, we therefore observe the same general trend as for universal grants or state take-overs so long as those targeted grants are binding on the poor district's public school funding choices: private school attendance falls as the result of centralization.

\section{Conclusion}

This paper simulates the impact of different public school financing schemes on private school attendance rates in a multi-district economy where the eligibility of a child to attend a public school is based on the parents' place of residence. The model is rather general and permits for households to choose where to live, whether to send their children to public or private schools and how to vote on local or state public school spending. The computable general equilibrium version of the model is then able to replicate most of the salient features observed in data for school districts in New Jersey. The results then suggest that careful attention to general equilibrium effects in school finance debates is indeed required for an accurate interpretation of some of the empirical developments as school finance laws have undergone revisions over the past three decades. For example, some of the results stand in stark contrast to the presumption that school finance centralization accompanied by little change in private school attendance rates is evidence against the hypothesis that centralization leads to less efficient utilization of resources within the public school sector.

More precisely, while a cursory look at the local public finance literature has persuaded 
some observers to conclude that centralization of public school finances in such an economy will lead to increases in private school attendance, the results here suggest the opposite (so long as centralization is not accompanied by substantial decreases in the efficiency of resource uses in public schools). In particular, the paper points to two distinct effects when pure local and pure state financing are compared. First, the "direct" (or partial equilibrium) effect of centralization leads to lower private school attendance in poor districts where resources for schools increase as a result of state financing and higher private school attendance in wealthy districts where the opposite is true. Second, an "indirect" (general equilibrium) effect emerges as state financing leads to a sharp increase in the opportunity cost of private school attendees choosing to reside in poor communities in order to take advantage of low cost housing and low property tax bases. When centralization occurs through state block grants rather than pure state financing, a third ("local discretion") effect emerges as private school attendance no longer increases in the wealthy districts because these districts are given the discretion to spend beyond the state block grant through local property tax revenues. On balance, the simulations suggest that private school attendance falls more under block grants than under pure state financing. Finally, when centralization involves the use of matching grants, a familiar fourth ("price subsidy") effect emerges, leading to yet greater declines in private school attendance under centralization. 
Table 1

Local Funding and Private School Enrollment (1990) ${ }^{31}$

\begin{tabular}{|c|c|c|}
\hline State & $\begin{array}{l}\text { Percent Private } \\
\text { of Enrolled }\end{array}$ & $\begin{array}{l}\text { Percent Local } \\
\text { Funding }\end{array}$ \\
\hline Delaware & 20.08 & 27.41 \\
\hline Hawaii & 19.56 & 3.78 \\
\hline Pennsylvania & 19.19 & 51.83 \\
\hline New Jersey & 18.83 & 57.62 \\
\hline New York & 17.68 & 54.13 \\
\hline Louisiana & 17.19 & 34.59 \\
\hline Maryland & 16.86 & 58.38 \\
\hline Rhode Island & 16.67 & 54.27 \\
\hline Illinois & 16.56 & 58.77 \\
\hline Massachusetts & 16.52 & 62.53 \\
\hline Wisconsin & 16.25 & 52.8 \\
\hline Connecticut & 15.91 & 55.82 \\
\hline Missouri & 15.46 & 54.94 \\
\hline Ohio & 14.46 & 53.43 \\
\hline Florida & 14.24 & 42.48 \\
\hline New Hampshire & 14.24 & 88.93 \\
\hline Nebraska & 13.45 & 76.21 \\
\hline United States & 12.82 & 46.67 \\
\hline California & 12.61 & 29.15 \\
\hline Michigan & 12.25 & 63.38 \\
\hline Minnesota & 11.97 & 43.59 \\
\hline Indiana & 11.58 & 37.06 \\
\hline Iowa & 11.18 & 46.13 \\
\hline Washington & 10.99 & 22.42 \\
\hline Virginia & 10.82 & 53.38 \\
\hline Mississippi & 10.67 & 28.41 \\
\hline Kansas & 10.5 & 52.28 \\
\hline Kentucky & 10.41 & 23.72 \\
\hline Georgia & 10.39 & 40.13 \\
\hline Alabama & 10.22 & 25.34 \\
\hline Oregon & 10.12 & 68.87 \\
\hline Colorado & 9.8 & 57.09 \\
\hline Tennessee & 9.53 & 43.17 \\
\hline Vermont & 9.26 & 60.73 \\
\hline South Carolina & 9.24 & 42.27 \\
\hline Arizona & 8.33 & 50.43 \\
\hline Texas & 8.33 & 50.6 \\
\hline Maine & 8.04 & 44.15 \\
\hline North Carolina & 7.85 & 30.08 \\
\hline South Dakota & 7.8 & 62.75 \\
\hline Nevada & 7.78 & 32.58 \\
\hline New Mexico & 7.54 & 12.76 \\
\hline Oklahoma & 7.51 & 35.33 \\
\hline Alaska & 7.47 & 21.58 \\
\hline Arkansas & 7.44 & 32.83 \\
\hline Montana & 7.32 & 44.37 \\
\hline North Dakota & 6.73 & 46.43 \\
\hline Idaho & 6.1 & 32.22 \\
\hline West Virginia & 5.55 & 26.97 \\
\hline Utah & 5.36 & 36.46 \\
\hline Wyoming & 5.11 & 43.79 \\
\hline
\end{tabular}

${ }^{31}$ Source: School District Data Book (1990) 
Table 2

\section{Characteristics of NJ School Districts}

\begin{tabular}{|lccc|}
\hline & \multicolumn{3}{c|}{ Representative School Districts } \\
& Low Income & Middle Income & High Income \\
& $(\mathrm{d}=1)$ & $(\mathrm{d}=2)$ & $(\mathrm{d}=3)$ \\
Mean House Value & $\$ 157,248$ & $\$ 192,867$ & $\$ 271,315$ \\
Median Household Income & $\$ 30,639$ & $\$ 45,248$ & $\$ 67,312$ \\
Per Pupil Spending & $\$ 6,702$ & $\$ 7,841$ & $\$ 8,448$ \\
Fraction Raised Locally & 0.52 & 0.77 & 0.87 \\
Percentage Private & 0.21 & 0.23 & 0.20 \\
\hline
\end{tabular}


Table 3

\section{Parameters of the Model}

\begin{tabular}{|c|c|c|c|c|c|}
\hline Population & $\begin{array}{c}\text { Neighborhood } \\
\text { Size }\end{array}$ & \multicolumn{4}{|c|}{ Utility and Production Function Exponents } \\
\hline $\mathrm{N}$ & $\mu\left(\mathrm{C}_{\mathrm{dh}}\right)$ & $\alpha$ & $\beta$ & $\rho$ & $\theta$ \\
\hline$[0,1]$ & 0.0667 & 0.22 & 0.650 & 0.475 & 0.5 \\
\hline District & State Aid & Min.Spend. & Size & & \\
\hline 1 & 0.3220 & 0.5000 & 0.333 & & \\
\hline 2 & 0.1800 & 0.5000 & 0.333 & & \\
\hline 3 & 0.1100 & 0.5000 & 0.333 & & \\
\hline $\mathrm{h}$ & \multicolumn{5}{|c|}{ Housing Quality Parameters $\left(\mathrm{k}_{\mathrm{dh}}\right)$} \\
\hline$d$ & 1 & 2 & 3 & 4 & 5 \\
\hline 1 & 0.820 & 0.882 & 0.930 & 0.978 & 1.021 \\
\hline 2 & 0.872 & 0.930 & 1.002 & 1.032 & 1.085 \\
\hline 3 & 0.930 & 0.950 & 1.063 & 1.182 & 1.267 \\
\hline
\end{tabular}




\section{Table 4}

Benchmark Equilibrium to Replicate New Jersey Data

\begin{tabular}{|lccccc|}
\hline & $\begin{array}{c}\text { Average } \\
\text { Income }\end{array}$ & $\begin{array}{c}\text { Avg Property } \\
\text { Values }\end{array}$ & $\begin{array}{c}\text { Fraction } \\
\text { Private }\end{array}$ & $\begin{array}{c}\text { Per Pupil } \\
\text { Spending }\end{array}$ & $\begin{array}{c}\text { School } \\
\text { Quality }\end{array}$ \\
District 1 & 3.1120 & 0.6121 & 0.2000 & 0.6652 & 0.4322 \\
District 2 & 4.6216 & 1.0720 & 0.2250 & 0.7910 & 0.6178 \\
District 3 & 6.5863 & 1.5248 & 0.1250 & 0.8621 & 0.7803 \\
\hline
\end{tabular}




\section{Table 5}

Pure Local and Pure State Public School

Finance Systems

\begin{tabular}{|l|c|c|c|c|c|c|c|c|c|c|}
\hline & \multicolumn{2}{|c|}{$\begin{array}{c}\text { Percent } \\
\text { Private }\end{array}$} & \multicolumn{2}{c|}{$\begin{array}{c}\text { Public School } \\
\text { Spending }\end{array}$} & \multicolumn{2}{c|}{$\begin{array}{c}\text { Public School } \\
\text { Quality }\end{array}$} & \multicolumn{2}{c|}{$\begin{array}{c}\text { Avg. Property } \\
\text { Values }\end{array}$} & \multicolumn{2}{c|}{$\begin{array}{c}\text { Tax + Payment } \\
\text { on Same House }\end{array}$} \\
\hline $\begin{array}{l}\text { Financin } \\
\text { g }\end{array}$ & Local & State & Local & State & Local & State & Local & State & Local & State \\
\hline District 1 & $30 \%$ & $22.5 \%$ & $\$ 5,000$ & $\$ 7,195$ & 0.3674 & 0.4616 & 0.6434 & 0.6177 & 0.6275 & 0.6775 \\
\hline District 2 & $20 \%$ & $17.5 \%$ & $\$ 7,326$ & $\$ 7,195$ & 0.6192 & 0.6316 & 1.1038 & 1.1800 & 1.0412 & 0.9632 \\
\hline District 3 & $10 \%$ & $15 \%$ & $\$ 10,215$ & $\$ 7,195$ & 0.8183 & 0.6841 & 1.5370 & 1.6490 & 1.3899 & 1.0841 \\
\hline Overall & $20 \%$ & $18.3 \%$ & $\$ 7,706$ & $\$ 7,195$ & 0.6204 & 0.5960 & --- & --- & --- & -- \\
\hline
\end{tabular}


Table 6

\section{Different Types of Stylized State Aid Formulae Applying to All Districts}

\begin{tabular}{|c|c|c|c|c|c|c|c|c|c|c|c|c|}
\hline \multicolumn{13}{|c|}{ (A) Block Aid } \\
\hline & \multicolumn{4}{|c|}{ District 1} & \multicolumn{4}{|c|}{ District 2} & \multicolumn{4}{|c|}{ District 3} \\
\hline $\mathrm{b}$ & $\begin{array}{c}\% \\
\text { Priv. }\end{array}$ & $\begin{array}{l}\text { Public } \\
\text { Spend }\end{array}$ & $\begin{array}{l}\text { Pub. } \\
\text { Qual. }\end{array}$ & $\begin{array}{l}\text { Prop. } \\
\text { Value }\end{array}$ & $\begin{array}{c}\% \\
\text { Priv. }\end{array}$ & $\begin{array}{l}\text { Public } \\
\text { Spend }\end{array}$ & $\begin{array}{l}\text { Pub. } \\
\text { Qual. }\end{array}$ & $\begin{array}{l}\text { Prop. } \\
\text { Value }\end{array}$ & $\begin{array}{c}\% \\
\text { Priv. }\end{array}$ & $\begin{array}{l}\text { Public } \\
\text { Spend }\end{array}$ & $\begin{array}{l}\text { Pub. } \\
\text { Qual. }\end{array}$ & $\begin{array}{l}\text { Prop. } \\
\text { Value }\end{array}$ \\
\hline 0.0 & $30 \%$ & $\$ 5,000$ & 0.367 & 0.642 & $20 \%$ & $\$ 7,326$ & 0.619 & 1.104 & $10 \%$ & $\$ 10,215$ & 0.818 & 1.537 \\
\hline 0.3 & $27.5 \%$ & $\$ 5,000$ & 0.378 & 0.634 & $20 \%$ & $\$ 7,267$ & 0.604 & 1.120 & $7.5 \%$ & $\$ 10,545$ & 0.905 & 1.680 \\
\hline 0.5 & $27.5 \%$ & $\$ 5,000$ & 0.372 & 0.557 & $20 \%$ & $\$ 6,588$ & 0.562 & 1.126 & $7.5 \%$ & $\$ 10,008$ & 0.820 & 1.622 \\
\hline 0.7 & $22.5 \%$ & $\$ 7,000$ & 0.453 & 0.502 & $17.5 \%$ & $\$ 7,000$ & 0.627 & 1.141 & $7.5 \%$ & $\$ 10,606$ & 0.855 & 1.703 \\
\hline \multicolumn{13}{|c|}{ (B) Matching Aid } \\
\hline & \multicolumn{4}{|c|}{ District 1} & \multicolumn{4}{|c|}{ District 2} & \multicolumn{4}{|c|}{ District 3} \\
\hline $\mathrm{m}$ & $\begin{array}{l}\% \\
\text { Priv. }\end{array}$ & $\begin{array}{l}\text { Public } \\
\text { Spend }\end{array}$ & $\begin{array}{l}\text { Pub. } \\
\text { Qual. }\end{array}$ & $\begin{array}{l}\text { Prop. } \\
\text { Value }\end{array}$ & $\begin{array}{c}\% \\
\text { Priv. }\end{array}$ & $\begin{array}{l}\text { Public } \\
\text { Spend }\end{array}$ & $\begin{array}{l}\text { Pub. } \\
\text { Qual. }\end{array}$ & $\begin{array}{l}\text { Prop. } \\
\text { Value }\end{array}$ & $\begin{array}{c}\% \\
\text { Priv. }\end{array}$ & $\begin{array}{l}\text { Public } \\
\text { Spend }\end{array}$ & $\begin{array}{l}\text { Pub. } \\
\text { Qual. }\end{array}$ & $\begin{array}{l}\text { Prop. } \\
\text { Value }\end{array}$ \\
\hline 0.0 & $30 \%$ & $\$ 5,000$ & 0.367 & 0.642 & $20 \%$ & $\$ 7,326$ & 0.619 & 1.104 & $10 \%$ & $\$ 10,215$ & 0.818 & 1.537 \\
\hline 0.2 & $22.5 \%$ & $\$ 5,000$ & 0.354 & 0.590 & $12.5 \%$ & $\$ 8,600$ & 0.673 & 1.101 & $7.5 \%$ & $\$ 13,375$ & 1.075 & 1.692 \\
\hline 0.4 & $12.5 \%$ & $\$ 5,373$ & 0.399 & 0.541 & $10 \%$ & $\$ 10,062$ & 0.757 & 1.088 & $5 \%$ & $\$ 14,042$ & 1.095 & 1.677 \\
\hline 0.6 & $10 \%$ & $\$ 5,528$ & 0.402 & 0.528 & $10 \%$ & $\$ 10,350$ & 0.770 & 1.074 & $2.5 \%$ & $\$ 15,979$ & 1.245 & 1.671 \\
\hline 0.8 & $0 \%$ & $\$ 5,796$ & 0.429 & 0.484 & $5 \%$ & $\$ 11,071$ & 0.822 & 1.050 & $0 \%$ & $\$ 19,403$ & 1.471 & 1.758 \\
\hline
\end{tabular}


Table 7

\section{Different Types of Stylized State Aid Formulae Applying to District 1 Only}

\begin{tabular}{|c|c|c|c|c|c|c|c|c|c|c|c|c|}
\hline \multicolumn{13}{|c|}{ (A) Block Aid } \\
\hline & \multicolumn{4}{|c|}{ District 1} & \multicolumn{4}{|c|}{ District 2} & \multicolumn{4}{|c|}{ District 3} \\
\hline $\mathrm{b}$ & $\begin{array}{l}\% \\
\text { Priv. }\end{array}$ & $\begin{array}{l}\text { Public } \\
\text { Spend }\end{array}$ & $\begin{array}{l}\text { Pub. } \\
\text { Qual. }\end{array}$ & $\begin{array}{l}\text { Prop. } \\
\text { Value }\end{array}$ & $\begin{array}{c}\% \\
\text { Priv. }\end{array}$ & $\begin{array}{l}\text { Public } \\
\text { Spend }\end{array}$ & $\begin{array}{l}\text { Pub. } \\
\text { Qual. }\end{array}$ & $\begin{array}{l}\text { Prop. } \\
\text { Value }\end{array}$ & $\begin{array}{c}\% \\
\text { Priv. }\end{array}$ & $\begin{array}{l}\text { Public } \\
\text { Spend }\end{array}$ & $\begin{array}{l}\text { Pub. } \\
\text { Qual. }\end{array}$ & $\begin{array}{l}\text { Prop. } \\
\text { Value }\end{array}$ \\
\hline 0.0 & $30 \%$ & $\$ 5,000$ & 0.367 & 0.642 & $20 \%$ & $\$ 7,326$ & 0.619 & 1.104 & $10 \%$ & $\$ 10,215$ & 0.818 & 1.537 \\
\hline 0.3 & $35 \%$ & $\$ 5,000$ & 0.339 & 0.811 & $20 \%$ & $\$ 7,369$ & 0.624 & 1.095 & $10 \%$ & $\$ 9,710$ & 0.800 & 1.548 \\
\hline 0.5 & $40 \%$ & $\$ 5,000$ & 0.330 & 0.975 & $17.5 \%$ & $\$ 7,498$ & 0.647 & 1.098 & $10 \%$ & $\$ 10,179$ & 0.822 & 1.569 \\
\hline 0.7 & $22.5 \%$ & $\$ 7,000$ & 0.446 & 1.050 & $15 \%$ & $\$ 8,496$ & 0.688 & 1.081 & $7.5 \%$ & $\$ 11,211$ & 0.937 & 1.608 \\
\hline \multicolumn{13}{|c|}{ (B) Matching Aid } \\
\hline & \multicolumn{4}{|c|}{ District 1} & \multicolumn{4}{|c|}{ District 2} & \multicolumn{4}{|c|}{ District 3} \\
\hline $\mathrm{m}$ & $\begin{array}{l}\% \\
\text { Priv. }\end{array}$ & $\begin{array}{l}\text { Public } \\
\text { Spend }\end{array}$ & $\begin{array}{l}\text { Pub. } \\
\text { Qual. }\end{array}$ & $\begin{array}{l}\text { Prop. } \\
\text { Value }\end{array}$ & $\begin{array}{c}\% \\
\text { Priv. }\end{array}$ & $\begin{array}{l}\text { Public } \\
\text { Spend }\end{array}$ & $\begin{array}{l}\text { Pub. } \\
\text { Qual. }\end{array}$ & $\begin{array}{l}\text { Prop. } \\
\text { Value }\end{array}$ & $\begin{array}{c}\% \\
\text { Priv. }\end{array}$ & $\begin{array}{l}\text { Public } \\
\text { Spend }\end{array}$ & $\begin{array}{l}\text { Pub. } \\
\text { Qual. }\end{array}$ & $\begin{array}{l}\text { Prop. } \\
\text { Value }\end{array}$ \\
\hline 0.0 & $30 \%$ & $\$ 5,000$ & 0.367 & 0.642 & $20 \%$ & $\$ 7,326$ & 0.619 & 1.104 & $10 \%$ & $\$ 10,215$ & 0.818 & 1.537 \\
\hline 0.2 & $32.5 \%$ & $\$ 5,000$ & 0.358 & 0.689 & $20 \%$ & $\$ 7,192$ & 0.603 & 1.105 & $10 \%$ & $\$ 10,236$ & 0.822 & 1.566 \\
\hline 0.4 & $30 \%$ & $\$ 5,544$ & 0.382 & 0.730 & $20 \%$ & $\$ 6,998$ & 0.600 & 1.091 & $10 \%$ & $\$ 10,432$ & 0.843 & 1.507 \\
\hline 0.6 & $25 \%$ & $\$ 6,025$ & 0.392 & 0.757 & $15 \%$ & $\$ 7,594$ & 0.661 & 1.100 & $10 \%$ & $\$ 10,364$ & 0.832 & 1.500 \\
\hline 0.8 & $15.5 \%$ & $\$ 6,502$ & 0.450 & 0.803 & $15 \%$ & $\$ 8,232$ & 0.634 & 1.095 & $7.5 \%$ & $\$ 9,693$ & 0.801 & 1.502 \\
\hline
\end{tabular}




\section{References}

Barro, Robert and Jong-Wha Lee (1997): “Schooling Quality in a Cross Section of Countries,” NBER working paper 6198.

Bayer, Patrick (1998): “The Role of Family Characteristics in Determining Demand for School Quality,” working paper, Stanford University.

Benabou, Roland (1996): "Heterogeneity, Stratification, and Growth: Macroeconomic Implications of Community Structure and School Finance," American Economic Review 86, 584-609.

Betts, Julian (1996): "Is there a Link between School Inputs and Earnings? Fresh Scrutiny of an Old Literature," in Does Money Matter? The Effect of School Resources on Student Achievement and Adult Success (Gary Burtless, ed.), Washington, DC: Brookings Institution, 141-91.

Black, Sandra E. (1999): “Do Better Schools Matter? Parental Valuation of Elementary Education,” Quarterly Journal of Economics 114(2), 577-99.

Brunner, Eric, Jon Sonstelie and Mark Thayer (2000): “Capitalization and the Voucher: An Analysis of Precinct Returns from California's Proposition 174," mimio, University of California - Santa Barbara.

Bureau of the Census (1992): 1990 Census of Population and Housing, Washington, DC: The Bureau of the Census.

Card, David and Alan Krueger (1992): "Does School Quality Matter? Returns to Education and the Characteristics of Public Schools in the United States," Journal of Political Economy 100,1-40.

Downes, T. and D. Schoeman (1998): "School Finance Reform and Private School Enrollment: Evidence from California," Journal of Urban Economics 43(3), 418-43.

Downes, Thomas (1996): "Do Differences in Heterogeneity and Intergovernmental Competition Help Explain Variation in the Private School Share? Evidence from Early California Statehood," Public Finance Quarterly 24(3), $291-318$.

Downes, Thomas and Shane Greenstein (1996): "Understanding the Supply Decision of Nonprofits: Modeling the Location of Private Schools," RAND Journal of Economics 27(2), 365-90.

Dunz, Karl (1985): “ Existence of Equilibrium with Local Public Goods and Houses,” SUNY-Albany Department of Economics Discussion Paper \#201.

Edel, M. and E. Scalar (1974): “Taxing, Spending and Property Values: Supply Adjustments in the Tiebout-Oates Model," Journal of Political Economy 82, 941-53.

Epple, Dennis, Radu Filimon and Thomas Romer (1993): "Existence of Voting and Housing Equilibrium in a System of Communities with Property Taxes," Regional Science and Urban Economics 23, 585-610.

Epple, Dennis and Richard Romano (1998): “Competition Between Private and Public Schools, Vouchers, and Peer-Group Effects” American Economic Review 88, 33-62.

Epple, Dennis and Richard Romano (1996): "Ends Against the Middle: Determining Public Service Provision when there are Private Alternatives," Journal of Public Economics 62, 297-325.

Epple, Dennis and Richard Romano (1995): "Public School Choice and Finance Policies, Neighborhood Formation, and the Distribution of Educational Benefits," working paper, University of Florida.

Epple, Dennis and Holger Sieg (1999): "Estimating Equilibrium Models of Local Jurisdictions,” Journal of Political Economy 107(4), 645-81. 
Fernandez, Raquel and Richard Rogerson (1998): "Public Education and Income Distribution: A Dynamic Quantitative; Evaluation of Education-Finance Reform," American Economic Review 88, 813-833.

Fernandez, Raquel and Richard Rogerson (1996): "Income Distributions, Communities and the Quality of Public Educaiton," Quarterly Journal of Economics 88, 135-164.

Hamilton, Bruce and Molly Macauley (1991): "Determinants and Consequences of the Private-Public School Choice," Journal of Urban Economics 29, 282-94.

Hamilton, Bruce (1975): “Zoning and Property Taxes in a System of Local Governments,” Urban Studies 12, $205-11$.

Hanushek, Eric (1999): "Some Findings from an Independent Investigation of the Tennessee STAR Experiment and from Other Investigations of Class Size Effects," in Earning and Learning: How Schools Matter (Mayer, S. and P. Peterson, eds.), Brookings: Washington, D.C.

Heckman, James, Anne Layne-Farrar and Petra Todd (1996): "Does Measured School Quality Really Matter? An Examination of the Earnings-Quality Relationship," in Does Money Matter? The Effect of School Resources on Student Achievement and Adult Success (Gary Burtless, ed.), Washington, DC: Brookings Institution, 192-289.

Hirschman, Alberto O. (1970): Exit, Voice and Loyalt, Harvard University Press, Cambridge, MA.

Hoxby, Caroline M. (1998): “All School Finance Equalizations are Not Created Equal,” NBER working paper 6792.

Hoxby, Caroline M. (1994): “Do Private Schools Provide Competition for Public Schools?”, NBER working paper 4978.

Krueger, Alan (1999): “Experimental Estimates of Education Production Functions," Quarterly Journal of Economics $114(2), 497-532$.

Long, James E. and Eugenia F. Toma (1988): "The Determinants of Private School Attendance, 1970-80," Review of Economics and Statistics 70(2), 351-57.

MaCurdy, Thomas and Thomas Nechyba (forthcoming): "How Does a Community's Demographic Composition Alter Its Fiscal Burdens?", in Demographic Change and Fiscal Policy (A. Auerbach and R. Lee, eds.), Cambridge U. Press.

Manski, C. (1993): "Identification of Endogenous Social Effects: the Reflection Problem,” Review of Economic Studies 60, 531-42.

McMillan, Robert (1998): “Competition, Parental Monitoring and Public School Quality,” working paper, Stanford University.

Murray, Sheila, William Evans and Robert Schwab (1998): "Education Finance Reform and the Distribution of Educational Resources," American Economic Review 88, 782-812.

National Center for Education Statistics (1995): School District Data Book v. 1.0, Washington, DC: US Department of Education.

Nechyba, Thomas (1999): "School Finance Induced Migration Patters: The Case of Private School Vouchers," Journal of Public Economic Theory 1(1), 1-46.

Nechyba, Thomas (2000): “Mobility, Targeting and Private School Vouchers," American Economic Review 90(1) (March), $130-46$.

Nechyba, Thomas (1997a): "Existence of Equilibrium and Stratification in Local and Hierarchical Public Good Economies with Property Taxes and Voting," Economic Theory 10, 277-304.

Nechyba, Thomas (1997b): "Local Property and State Income Taxes: The Role of Interjurisdictional Competition and Collusion," Journal of Political Economy 105(2), 351-84. 
Nechyba, Thomas (1996): “A Computable General Equilibrium Model of Intergovernmental Aid,” Journal of Public Economics 62, 363-97.

Nechyba, Thomas and Michael Heise (2000): "School Finance Reform: Introducing the Choice Factor," in City Schools: Lessons from New York (J. Viteritti and D. Ravich, eds.), Baltimore: John Hopkins University Press.

Nechyba, Thomas and Robert Strauss (1998): "Community Choice and Local Public Services: A Discrete Choice Approach," Regional Science and Urban Economics 28(1), 51-74.

Oates, Wallace (1972): Fiscal Federalism, Harcourt Brace Jovanovich, Inc.

Oates, Wallace (1969): “The Effects of Property Taxes and Local Public Spending on Property Values: An Empirical Study of Tax Capitalization and the Tiebout Hypothesis," Journal of Political Economy 77(6), 957-71.

Reback, Randall (2000): “Capitalization under School Choice Programs: Are the Winners Really the Losers?” mimio, University of Michigan.

Rose-Ackerman, Susan (1979): "Market Models of Local Government: Exit, Voting and the Land Market," Journal of Urban Economics 6, 319-37.

Schmidt, Amy B. (1992): "Private School Enrollment in Metropolitan Areas," Public Finance Quarterly 20, 298-320.

Solon, Gary (1992): “Intergenerational Income Mobility in the United States,” American Economic Review 82, $393-409$.

Sonstelie, J. (1979): “Public School Quality and Private School Enrollment,” National Tax Journal 32, 343-53.

Sonstelie, J., E. Brunner and K. Ardon (2000): For Better or For Worse? School Finance Reform in California, Public Policy Institute of California: San Francisco, CA.

Sonstelie, J. and F. Silva (1995): “Did Serrano Cause a Decline in School Spending,” National Tax Journal, 199-216.

Tiebout, C. (1956): “A Pure Theory of Local Expenditures,” Journal of Political Economy 65, 416-24.

Zimmerman, David (1992): “Regression Toward Mediocrity in Economic Stature,” American Economic Review 82, $409-29$. 